\title{
Cytoplasmic localization of the white phase- specific WH11 gene product of Candida albicans
}

\author{
Klaus Schröppel, $\uparrow$ T. Srikantha, Deborah Wessels, Melanie DeCock, \\ Shawn R. Lockhart and David R. Soll
}

Author for correspondence: David R. Soll. Tel: +1 319335 1117. Fax: +1 3193352772.

Department of Biological Sciences, University of lowa, lowa City, IA 52242, USA

\begin{abstract}
Cells of Candida albicans wo-1 switch frequently, spontaneously and reversibly between a white and opaque phase. The white-opaque transition involves the regulation of phase-specific genes. In the white budding phase, cells express the white phase-specific gene WH11, which encodes a protein with homology to the heat shock protein Hsp12 of Saccharomyces cerevisiae. A recombinant Wh11 protein has been synthesized, purified to apparent homogeneity and used to generate a rabbit polyclonal antiserum. The antiserum was used to localize the Wh11 protein in white phase cells. Wh11 is distributed throughout the cytoplasm but appears to be excluded from vesicles, plasma membrane and nucleus. An analysis by Western blotting of Wh11 expression in a number of $C$. albicans strains and related species suggests a correlation between round budding cell shape and expression.
\end{abstract}

Keywords: Candida switching, white-opaque transition, bud-hypha transition, recombinant Wh11 protein, cell shape

\section{INTRODUCTION}

Most strains of Candida albicans can switch between a limited number of general phenotypes distinguishable by colony morphology (Slutsky et al., 1985; Pomés et al., 1985; Soll, 1992). Switching occurs spontaneously, is reversible and has a pleiotropic effect on phenotype. It can affect phenotypic characteristics as diverse as cellular morphology (Slutsky et al., 1987; Anderson \& Soll, 1987), antigenicity (Anderson et al., 1989, 1990), secretion of acid proteinase (Morrow et al., 1992; White et al., 1993; Hube et al., 1994), wall morphology (Anderson \& Soll, 1987; Anderson et al., 1990), pathogenicity in mouse models (Ray \& Payne, 1990), sensitivity to white blood cells (Kolotila \& Diamond, 1990) and adherence (Kennedy et al., 1988; Vargas et al., 1994). Switching frequently and reversibly alters phenotypic traits in a combinatorial fashion, including traits involved in pathogenesis. Therefore, it has been suggested that switching provides a mechanism for rapid adaptation to changes in the environment.

In the case of $C$. albicans WO-1, cells switch reversibly and at high frequency $\left(10^{-2}-10^{-4}\right)$ between a white and opaque

\footnotetext{
† Present address: Institut für Klinische Mikrobiologie und Immunologie, FAU Universitat Erlangen, Wasserturmstrasse 3, 91054 Erlangen, Germany
}

colony-forming phenotype, which are distinguishable not only by colony morphology, but also by ultrastructure (Slutsky et al., 1987). Switching in WO-1 has been followed back and forth through more than 100 sequential switches in a single lineage with no effects on either the alternative phenotypes or the subsequent frequency of switching (M. Rotman \& D. R. Soll, unpublished observations), suggesting that switching is not a random event, but rather a highly programmed process. This interpretation has been reinforced, in recent years, by the identification of both a white-phase-specific gene (Srikantha \& Soll, 1993) and several opaque-phasespecific genes (Morrow et al., 1992, 1993; White et al., 1993; Hube et al., 1994). In addition, the promoter of the white-phase-specific gene, $\mathrm{WH} 11$, has been functionally characterized and demonstrated to contain two cis-acting transcription activation domains which function synergistically in the activation of $W H 11$ transcription in the white phase (Srikantha et al., 1995). Finally, gel retardation experiments have demonstrated the presence of whitephase-specific factors which bind to the two transcription activation domains of WH11 (Srikantha et al., 1995). These results demonstrate that switching involves a precise programme of phase-specific gene regulation.

The regulation of $W H 11$ gene expression is particularly interesting for a number of reasons. Firstly, as noted, it is regulated by the white-opaque transition (Srikantha \& 
Soll, 1993). It is selectively transcribed in the white budding phenotype, but not in the opaque budding phase. Secondly, it is also regulated by the bud-hypha transition. It is expressed in the white budding phase, but not in the white hyphal phase (Srikantha \& Soll, 1993) and, therefore, represents the first bud-specific gene in C. albicans. Its expression correlates with a round cell phenotype (i.e. it is expressed in the round budding phase, but is deactivated in both the elongate opaque budding phase and the elongate hyphal phase). Thirdly, it is homologous to the glucose and lipid-regulated protein Glp1 of Saccharomyces cerevisiae (Stone et al., 1990), which has also been shown to be heat-shock protein Hsp12 (Praekelt \& Meacock, 1990; Varela et al., 1995). To begin to understand the role of the $W H 11$ gene product in switching, we have generated a rabbit polyclonal antiserum against a recombinant Wh11 protein and have used this antiserum to localize the WH11 gene product in white budding cells. In addition, we have screened the protein extracts of budding cells from a number of medically important Candida species to test the relationship between cell shape and the presence of a Wh11 homologue.

\section{METHODS}

Strains. Candida albicans strains 3153A and WO-1 represent highly characterized laboratory strains from the Soll laboratory (e.g. Slutsky et al., 1985, 1987). Isolates Candida tropicalis 996-28, Candida guillermondii 1228-32, Candida lusitaniae 1225-10, Candida parapsilosis 1345-22, Torulopsis glabrata 7549, Candida kefyr 881-02, Candida krusei 1225-24 and Trichosporon beigelii 1265-15 were generous gifts of Dr Michael Pfaller, University of Iowa, IA, USA. C. tropicalis J941810 was a generous gift from Dr Frank Odds, Janssen Research Foundation, Beerse, Belgium. Candida shehatae 34887 was purchased from the American Type Culture Collection, Bethesda, MD, USA. Candida famata 101 was from the Soll laboratory collection. Saccharomyces cerevisiae LA93-89 was a generous gift from Dr Jack Sobel, Wayne State University, Detroit, MI, USA. Dictyostelium discoideum Ax3 clone RC3 represents a highly characterized strain from the Soll laboratory (Soll, 1979; Wessels et al., 1996). The atypical $C$. albicans strain was isolated in Montpellier, France by C. Pujol and characterized for isoenzyme patterns, Southern blot hybridization with specific probes and sugar assimilation pattern. It was similar in all respects to Candida dubliniensis NCPF 3108 (C. Pujol, S. Joly, M. Tibayrenc \& D. R. Soll, unpublished observations), obtained from the British National Collection of Pathogenic Fungi, PHLS, Colindale, UK. C. albicans CAI-4 was a generous gift from $\mathrm{Dr}$ W. Fonzi, Georgetown University, School of Medicine, Washington, DC, USA.

Growth and maintenance of yeast strains. C. albicans WO-1 was maintained on nutrient agar slants containing modified Lee's medium (Bedell \& Soll, 1979). For experimental purposes, cells were plated at low density and cells from a white or from an opaque colony were inoculated into separate flasks containing modified Lee's liquid medium. Cultures were shaken at 250 r.p.m. at $25^{\circ} \mathrm{C}$. For experimental use, cells were harvested at mid-exponential phase. Cell cultures were always assessed for phenotypic homogeneity (i.e. percentage white or opaque cells) prior to use in an experiment. All white or opaque cultures were over $99 \%$ homogeneous for the respective phenotype. Other yeast species employed in this study were maintained either on Sabouraud's agar slants $(1 \%, \mathrm{w} / \mathrm{v}$, yeast extract, $4 \%, \mathrm{w} / \mathrm{v}$, glucose) or YPD agar slants ( $1 \%$ yeast extract, $2 \%, \mathrm{w} / \mathrm{v}, \mathrm{Bacto}$ peptone, $2 \%$ glucose). For experimental purposes, cells of these species were grown to mid-exponential phase in YPD broth.

Construction of the recombinant plasmid. The WH11 ORF (Srikantha \& Soll, 1993) was fused to the glutathione-Stransferase gene (GST) in pGEX-2T (Smith \& Johnson, 1988) (Pharmacia) by the following procedure. A PCR product of $201 \mathrm{bp}$ was generated using a pair of oligonucleotide primers (primer I: 5' ATGTCCGACT'TAGGTAG 3'; primer II: 5' GGATCCATTTGGAATCACCAAA $3^{\prime}$ ), complementary to the $5^{\prime}$ and $3^{\prime}$ ends of the WH11 ORF, and PWhgP.4 (Srikantha \& Soll, 1993), containing the WH11 gene, as a template. The PCR product was gel-purified, digested with $\mathrm{Bam} \mathrm{HI}$ and HincII and end-repaired using T4 DNA polymerase to ensure in-frame fusion. Plasmid pGEX-2T was digested with EcoRI followed by end repair with Klenow DNA polymerase. The PCR product was then inserted between the filled-in EcoRI sites of pGEX-2T to generate plasmid pWHOR.2. The in-frame fusion of the GST ORF and the WH11 ORF in PWHOR.2 was confirmed by dideoxy sequence analysis (Sanger et al., 1977) using Sequenase II according to the manufacturer's specifications (USB).

\section{Expression and purification of recombinant Wh11 protein.} Escherichia coli LE392 was transformed with pWHOR.2 and an ampicillin-resistant clone was inoculated into $5 \mathrm{ml} \mathrm{LB}$ broth containing $100 \mu \mathrm{g}$ ampicillin $\mathrm{ml}^{-1}$. This culture was grown overnight at $37^{\circ} \mathrm{C}$ and used as an inoculum for $250 \mathrm{ml} \mathrm{LB}$ medium. The cells were grown at $37^{\circ} \mathrm{C}$ to an $\mathrm{OD}_{600}$ of 1.0 prior to the induction of fusion protein synthesis. To induce fusion protein synthesis, IPTG was added to the culture to a final concentration of $150 \mu \mathrm{M}$ and the culture was incubated for an additional $4 \mathrm{~h}$. The bacteria were harvested, washed in TBS $(50 \mathrm{mM}$ Tris, $\mathrm{pH} 7 \cdot 5,150 \mathrm{mM} \mathrm{NaCl})$ containing $0.1 \%$ Triton $\mathrm{X}-100$, lysed using a French press at 20000 p.s.i. and the lysate was centrifuged at $20000 \mathrm{~g}$ for $15 \mathrm{~min}$. Glutathione-sephadex was added to the supernatant containing the rWh11 fusion protein (Pharmacia). The glutathione-Sepharose had previously been equilibrated with TBS $/ 0.1 \%$ Triton $\mathrm{X}-100$ and the mixture incubated for $60 \mathrm{~min}$ at $4{ }^{\circ} \mathrm{C}$. After incubation for $1 \mathrm{~h}$, the Sepharose beads were pelleted by low speed centrifugation, washed twice with thrombin cleavage buffer $(50 \mathrm{mM}$ Tris $/ \mathrm{HCl}$, $\mathrm{pH} 7.5,150 \mathrm{mM} \mathrm{NaCl}, 2.5 \mathrm{mM} \mathrm{CaCl}$ ) and the pellet resuspended and incubated for $90 \mathrm{~min}$ at $37^{\circ} \mathrm{C}$ in an equivalent volume of thrombin cleavage buffer containing 50 units of thrombin (Sigma). $\mathrm{NaCl}$ was then added to the reaction mixture to a final concentration of $1.5 \mathrm{M}$ and the mixture was centrifuged at $5000 \mathrm{~g}$ for $10 \mathrm{~min}$. The supernatant was mixed with an equal volume of $2 \times$ SDS-PAGE loading buffer to final concentrations of $4 \%(\mathrm{w} / \mathrm{w})$ SDS, $12 \%(\mathrm{w} / \mathrm{v})$ glycerol, $50 \mathrm{mM}$ Tris $/ \mathrm{HCl}, \mathrm{pH} 6.8,2 \%(\mathrm{v} / \mathrm{v})$ 2-mercaptoethanol and $0.01 \%$ Serva Blue G. The mixture was heated to $80^{\circ} \mathrm{C}$ for $25 \mathrm{~min}$, loaded on a preparative $12 \%$ tricine-SDS polyacrylamide gel (Schägger et al., 1987) and electrophoresed at $80 \mathrm{~V}$ until the dye reached the bottom of the gel. The rWh11 fusion protein was localized by incubating the gel in ice-cold $250 \mathrm{mM}$ potassium acetate. The identified rWh11 band was excised and protein electroeluted for $25 \mathrm{~h}$ at $200 \mathrm{~V}$ using the Elutrap System (Schleicher \& Schuell). The eluted $\mathrm{rWh} 11$ protein was dialysed against PBS ( $3 \mathrm{mM} \mathrm{KCl}, 137 \mathrm{mM} \mathrm{NaCl}, 2 \mathrm{mM} \mathrm{KH}_{2} \mathrm{PO}_{4}, 7 \mathrm{mM}$ $\mathrm{Na}_{2} \mathrm{HPO}_{4}, \mathrm{pH} 7 \cdot 4$ ) diluted to $800 \mu \mathrm{g}$ protein $\mathrm{ml}^{-1}$ and stored at $4{ }^{\circ} \mathrm{C}$.

Generating an anti-rWh11 antiserum. A $0.5 \mathrm{ml}$ sample containing $400 \mu \mathrm{g}$ protein was emulsified with $0.5 \mathrm{ml}$ Freund's complete adjuvant and injected intradermally at 10 independent sites in the back of a New Zealand White rabbit. Subsequent injections with Freund's incomplete adjuvant were performed after $30,60,93$ and 152 subsequent days at respective protein doses of $400,400,100$ and $100 \mu \mathrm{g}$ into the hip muscle of the 
animal. Fourteen days after the last injection, $5 \mathrm{ml}$ blood was collected and allowed to clot at $4{ }^{\circ} \mathrm{C}$. The clot was removed by centrifugation and cell-free supernatant was stored at $-20^{\circ} \mathrm{C}$. The presence of $\mathrm{rWh} 11$-specific antibodies in the serum was tested by Western blot analysis.

Preparation of cell-free protein extracts. Cells were harvested from broth cultures and washed twice in a solution containing $150 \mathrm{mM} \mathrm{NaCl}$ and $50 \mathrm{mM}$ Tris $/ \mathrm{HCl}, \mathrm{pH} 8 \cdot 3$. Approximately $10^{9}$ cells were transferred to $2 \mathrm{ml}$ microfuge tubes and resuspended in $1 \mathrm{ml}$ lysis buffer $(150 \mathrm{mM} \mathrm{NaCl}, 50 \mathrm{mM}$ Tris/ $\mathrm{HCl}, \mathrm{pH} 8.3,0 \cdot 1 \%$ 2-mercaptoethanol, $1 \mathrm{mM}$ PMSF, $2 \mathrm{mM} \varepsilon$-aminocaproic acid, $2 \mathrm{mM}$ pepstatin, $0.6 \mu \mathrm{M}$ leupeptin, $2 \mu \mathrm{g}$ chymostatin $\mathrm{ml}^{-1}, 50 \mu \mathrm{g}$ aprotinin $\mathrm{ml}^{-1}$ ) containing 1 vol. $0.4 \mathrm{~mm}$ glass beads. Cells were disrupted in a Bead Beater II (Biospec Products) through 10 cycles of $15 \mathrm{~s}$ duration interspersed with 30 s periods of cooling in an ice bath. Lysates were clarified by high speed centrifugation at $10000 \mathrm{~g}$ for $20 \mathrm{~min}$ at $4{ }^{\circ} \mathrm{C}$. Samples were stored at $-70^{\circ} \mathrm{C}$. Protein concentration was determined by the method of Bradford (1976) (Bio-Rad).

Western blot analysis. Cell-free extract containing 20-25 $\mu \mathrm{g}$ protein was heated to $80^{\circ} \mathrm{C}$ for $25 \mathrm{~min}$ in SDS-PAGE loading buffer, loaded on a $12 \%(\mathrm{w} / \mathrm{v})$ tricine-SDS polyacrylamide gel (Schägger et al., 1987) and electrophoresed at $80 \mathrm{~V}$ until the dye reached the bottom of the gel. The gel was then either stained with Coomassie Blue R250 or transferred to Immobilon-P membrane (Millipore) using a semi-dry blotting technique according to the manufacturer's specifications. Prior to transfer, the gel and membrane were soaked in cathode transfer buffer (25 mM Tris/HCl, pH $9.4,40 \mathrm{mM}$ glycine, $20 \%, \mathrm{v} / \mathrm{v}$, methanol). The transfer of separated proteins from the gel to membranes was performed for $30 \mathrm{~min}$ at $0.33 \mathrm{~mA} \mathrm{~cm}^{-2}$, for $30 \mathrm{~min}$ at $0.50 \mathrm{~mA} \mathrm{~cm}^{-2}$ and finally for $30 \mathrm{~min}$ at $0.66 \mathrm{~mA} \mathrm{~cm}^{-2}$. Following transfer, the membrane was washed for $2 \mathrm{~h}$ in PBS and incubated either in a solution of $0.1 \%$ India Ink and $0.3 \%$ Tween-20 to visualize proteins, or in blocking solution $5 \%$, $\mathrm{w} / \mathrm{v}$ Carnation milk powder, $1 \%, \mathrm{w} / \mathrm{v}, \mathrm{BSA}, 0.1 \%, \mathrm{v} / \mathrm{v}$, Tween-20 in PBS) for $15 \mathrm{~h}$ at room temperature for immunostaining. For immunostaining, the membrane was transferred to fresh blocking solution containing a 1:2500 dilution of rabbit anti-rWh11 antiserum and incubated for $60 \mathrm{~min}$ at room temperature. The membrane was rinsed six times for $5 \mathrm{~min}$ in a solution containing PBS $/ 0.2 \%$ Tween 20 and incubated in a solution containing a $1: 2500$ dilution of goat anti-rabbit antiserum conjugated with alkaline phosphatase (Life Technologies) in blocking solution for $30 \mathrm{~min}$. The membrane was washed three times in a solution of PBS $/ 0.2 \%$ Tween- 20 and two times in TBS. For detection of immunostained proteins, the membrane was soaked in AP buffer ( $100 \mathrm{mM}$ Tris, $\mathrm{pH} 9.5$, $100 \mathrm{mM} \mathrm{NaCl}, 5 \mathrm{mM} \mathrm{MgCl} 2$ ) containing NBT-BCIP according to the manufacturer's recommendations (Promega). Staining of bands was terminated by rinsing in $100 \mu \mathrm{M}$ EDTA.

Indirect immunofluorescent staining of cells. Cells were washed in water and resuspended at a density of $10^{7} \mathrm{ml}^{-1}$. One millilitre was mixed with $0.5 \mathrm{ml}$ freshly prepared $12 \%(\mathrm{v} / \mathrm{v})$ paraformaldehyde, $\mathrm{pH} 8 \cdot 0$. The cell mixture was incubated for $30 \mathrm{~min}$ at $25^{\circ} \mathrm{C}$, pelleted, resuspended in a solution containing $4 \%(\mathrm{w} / \mathrm{v})$ paraformaldehyde and $5 \%(\mathrm{v} / \mathrm{v})$ DMSO in PBS, $\mathrm{pH} 7 \cdot 4$, and incubated first for $30 \mathrm{~min}$ at $25^{\circ} \mathrm{C}$, then for $60 \mathrm{~min}$ at $37^{\circ} \mathrm{C}$. Fixed cells were then washed twice in a solution of PBS containing $5 \%$ DMSO, resuspended in $2.5 \mathrm{ml}$ SCM $(1.2 \mathrm{M}$ sorbitol, $50 \mathrm{mM}$ sodium citrate, $\mathrm{pH} 5 \cdot 9,0 \cdot 1 \%$ mercaptoethanol, $5 \mathrm{mM} \mathrm{MgCl}$ ) containing $3 \mathrm{mg}$ Zymolyase $100 \mathrm{~T}$ (Seikagaku America), $3 \mathrm{mg}$ Novozyme 234 (Sigma) and $5 \mathrm{mg} \beta$ glucuronidase (Sigma) and incubated for 10-15 min in the case of opaque phase cells or $180 \mathrm{~min}$ in the case of white phase cells. Cell wall digestion was monitored by phase contrast micro- scopy. Cells were washed twice in SCM and once in a solution containing $1 \cdot 2 \mathrm{M}$ sorbitol and $100 \mathrm{mM}$ Tris/ $\mathrm{HCl}, \mathrm{pH} 8 \cdot 3$. Cells were permeabilized by incubating them in a solution containing PBS, $5 \%$ DMSO and $0.2 \%$ Triton X-100 for $10 \mathrm{~min}$ at $25^{\circ} \mathrm{C}$ and washed in PBS, pH 8.2 , containing $5 \%$ DMSO and $1 \%$ BSA. Cells were incubated in blocking solution $(25 \%, \mathrm{v} / \mathrm{v}$, goat serum, $10 \%$ Carnation milk powder, $5 \%$ DMSO in PBS) for $60 \mathrm{~min}$ and then in a 1:500 dilution of rabbit anti-rWh11 antiserum in blocking solution for $90 \mathrm{~min}$, followed by five washes in a solution of PBS containing $5 \%(\mathrm{v} / \mathrm{v})$ DMSO. Cells were incubated in a 1:300 dilution of FITC-labelled goat antirabbit IgG antiserum (Organon Teknika Corp.) in blocking solution for $45 \mathrm{~min}$ in a dark chamber. Cells were washed six times with PBS followed by staining with 4,6-diamino-2phenylindole (DAPI) $\left(0.02 \mu \mathrm{g} \mathrm{m}^{-1}\right)$ for $5 \mathrm{~min}$. Cells were finally pelleted by centrifugation at $6000 \mathrm{~g}$, resuspended in $50 \mu \mathrm{l}$ Vectashield Mounting medium (Vector Labs) and spread on slides for microscopic analysis. For visualizing cells stained with FITC-labelled goat anti-rabbit IgG antiserum, a blue I $450 \mathrm{MM}$ excitation filter was employed and for DAPI-stained cells a UV $365 \mathrm{MM}$ excitation filter was employed. Cells were photographed using epiluminescent fluorescence in a Zeiss ICM405 inverted microscope. The same preparations were examined with a Bio-Rad $600 \mathrm{MRE}$ confocal microscope.

\section{RESULTS}

\section{Expression and purification of recombinant Wh11 protein and characterization of polyclonal anti- rWh11 antiserum}

The entire protein-coding region of $W H 11$ cDNA was fused in-frame to GST in pWHOR.2 and the resulting plasmid was used to transform E. coli LE392. After induction with IPTG, the fusion protein was affinitypurified with glutathione cross-linked to Sepharose (Smith \& Johnson, 1988). The affinity-purified preparation was enriched for a protein of $32 \mathrm{kDa}$, the estimated size of the GST-Wh11 fusion protein (Fig. 1, lane 2). The

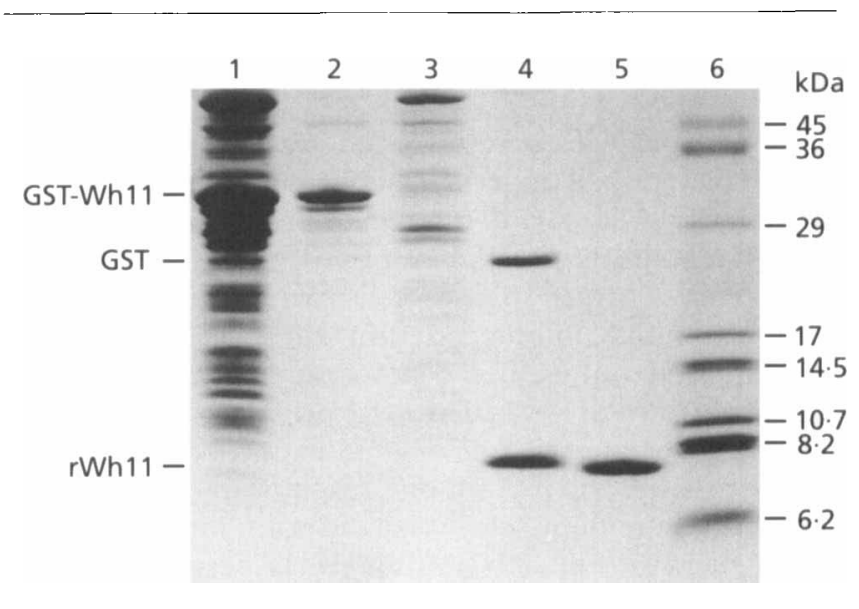

Fig. 1. Affinity purification of rWh11 protein. The figure shows a polyacrylamide gel containing Coomassie-stained proteins following separation by SDS-PAGE. Lanes: 1 , total protein from E. coli LE392 transformed with pWHOR.2; 2 , protein affinitypurified with glutathione-Sepharose; 3, flow-through after affinity purification; 4, GST and rWh11 after cleavage with thrombine; 5, rWh11 after preparative SDS-PAGE; 6 , molecular mass markers. Lane 5 demonstrates the relatively pure rWh11 subsequently used to immunize a rabbit. 
(a)

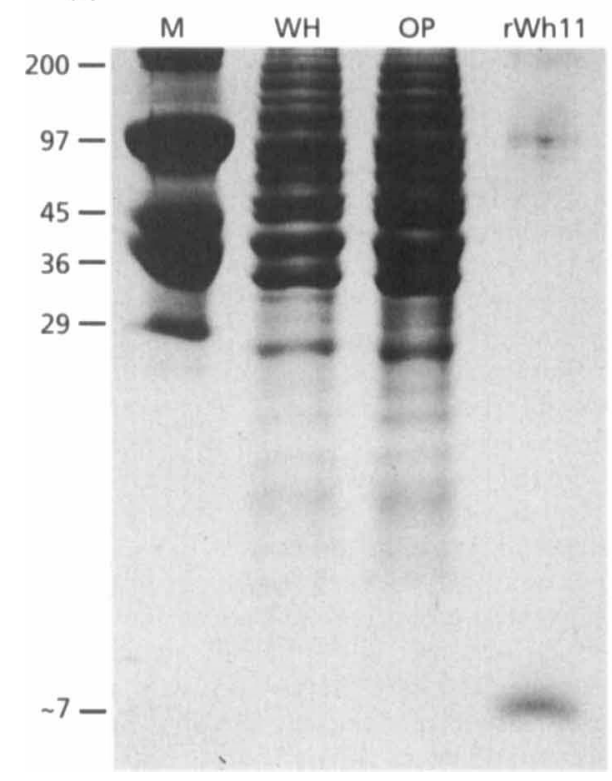

(b)

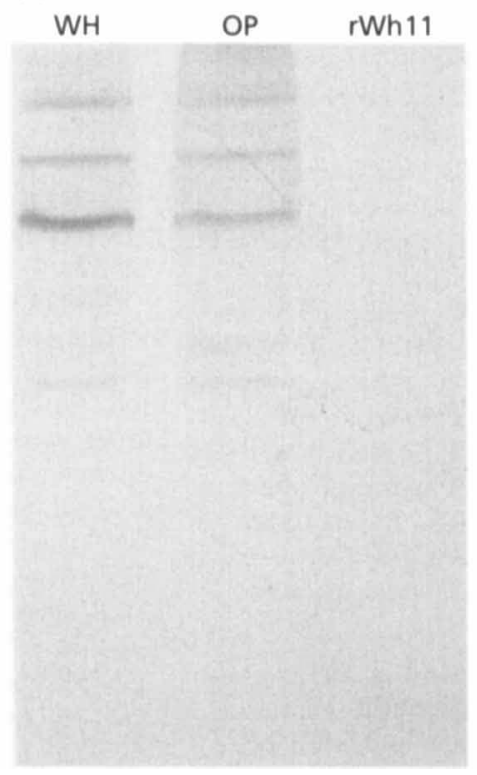

(c)

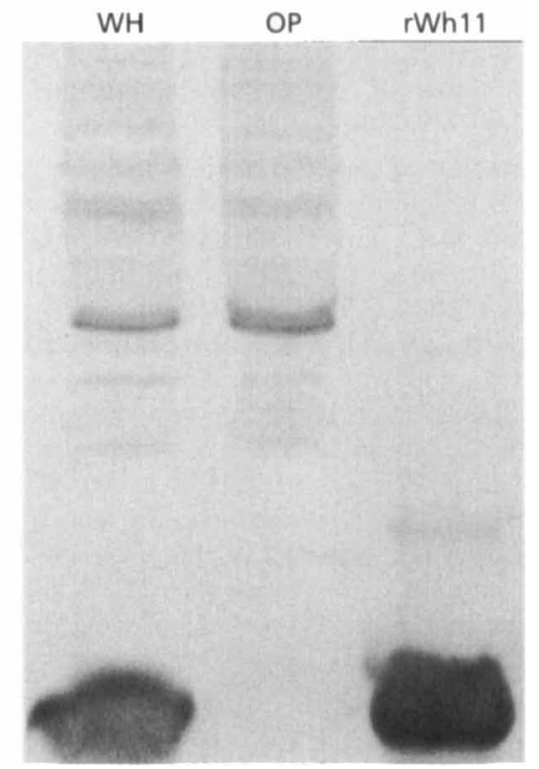

Fig. 2. Analysis of the antiserum generated against the rWh11 protein. (a) Polyacrylamide gel containing Coomassiestained proteins following separation by SDS-PAGE. Lanes: $M$, molecular mass markers; WH, total protein from white phase cells; OP, total protein from opaque phase cells; rWh11, purified rWh11 protein. (b) Western blot of protein extract from white phase cells $(\mathrm{WH})$, protein extract from opaque phase cells (OP) and rWh11 probed with rabbit preimmune serum. Note that both white and opaque phase protein extracts show similar patterns of lightly stained high molecular mass proteins. (c) Western blot of protein extract from white phase cells (WH), protein extract from opaque phase cells (OP) and rWh11 probed with rabbit immune serum (anti-rWh11 antiserum). Note the intense band of approximately $7 \mathrm{kDa}$ in the white phase protein extract but not in the opaque phase protein extract. Note also the similar molecular mass of rWh11 and the major white phase antigen.

fusion protein was then cleaved with thrombin, resulting in a protein of approximately $25 \mathrm{kDa}$, the size of the GST polypeptide, and in a protein of approximately $7 \mathrm{kDa}$, the predicted size of the rWh11 protein (Fig. 1, lane 4). After preparative SDS-PAGE, the rWh11 protein was purified to apparent homogeneity (Fig. 1, lane 5). This protein preparation was used to immunize a rabbit.

The polyclonal antiserum raised against the rWh11 recombinant polypeptide stained purified rWh11 in Western blots (Fig. 2c). To demonstrate the specificity of the anti-rWh11 antiserum, the cell-free protein extracts of white and opaque phase cells were stained with preimmune and immune serum in a Western blot. Preimmune serum exhibited non-specific staining of the same array of high molecular mass protein bands in both white and opaque cell-free protein extracts (Fig. 2b). In neither case did the preimmune serum stain a protein of $\sim 7 \mathrm{kDa}$. Preimmune serum also did not stain the purified rWh11 protein (Fig. 2b). Although the serum obtained from the rabbit immunized with $\mathrm{rWh} 11$ protein stained an identical array of high molecular mass proteins in both white and opaque cell extracts, it selectively stained a major protein of approximately $7 \mathrm{kDa}$ in the white cell extract but not in the opaque cell extract (Fig. 2c). The level of staining of the $7 \mathrm{kDa}$ protein was dramatically greater than that of the higher molecular mass proteins. Absorption with protein from bacteria transformed with control plasmid pGx2T without the $W H 11$ insert, did not remove antibody reacting with the high molecular mass proteins. These bands, therefore, represent cross-reacting antigens which are not phase-specific. The white-phasespecific antigen exhibited the same molecular mass as the rWh11 protein (Fig. 2c). These results demonstrate that the anti-rWh11 antiserum selectively stains the WH11 gene product. The similarity of the molecular size of rWh11 protein and the antiserum-identified antigen in white cell extract suggests that Wh11 is not subject to major post-translational modification.

\section{The anti-rWh11 antiserum selectively stains the cytoplasm of white phase cells in a punctate fashion}

To assess the cellular location of the WH11 gene product in white phase budding cells, fixed white phase cells were treated with anti-rWh11 antiserum and then stained with FrTC-labelled goat anti-rabbit IgG antiserum. Examples of the phase contrast images are presented in Fig. $3 \mathrm{a}-\mathrm{d}$, and respective fluorescently stained white phase budding cell images are presented in Fig. $3 \mathrm{a}^{\prime}-\mathrm{d}^{\prime}$. White budding cells stained in a punctate fashion throughout the cytoplasm. There was no indication of either cortical or membrane localization. When stained white cells were examined by confocal microscopy, a similar pattern was observed (Fig. 3e-j). Staining appeared throughout the cytoplasm and, again, no specific localization was evident either in the outer cortex of the cytoplasm or plasma 

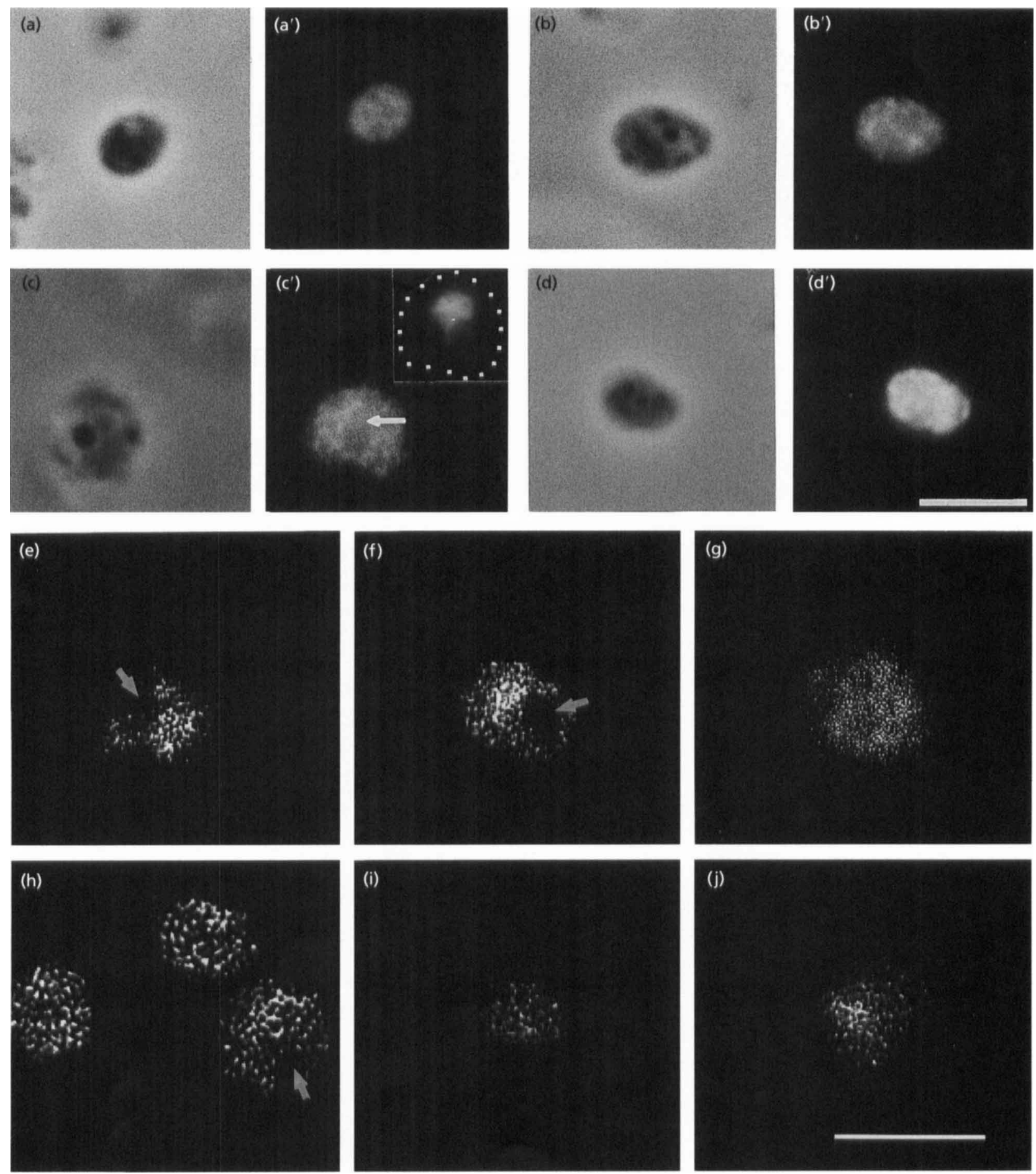

Fig. 3. White phase budding cells stained with anti-rWh11 antiserum. Staining was accomplished by labelling anti-rWh 11 antiserum-treated preparations with FITC-conjugated goat anti-rabbit IgG antiserum. (a-d) and (a'-d') Phase contrast and anti-rWh11 antiserum-stained epifluorescent images, respectively, of four white phase cells in the budding phase of growth. (e-j) Confocal images of anti-rWh11 antiserum-stained white phase cells in the budding phase of growth. Regions in the cell excluding Wh11 antigen are noted in panels $\left(c^{\prime}\right),(e),(f)$ and $(h)$ by white arrows. In $\left(c^{\prime}\right)$ there is an insert of the DAPI-stained nucleus of the cell; the cell perimeter in the insert is distinguished by white dots. Bars, $5 \mu \mathrm{m}$.

membrane. Staining appeared to be excluded from a single region in the cell interior (e.g. Fig. $3 c^{\prime}, e, f, h$ ), and double staining with anti rWh11 antiserum and DAPI
(Fig. 3c') suggested that these exclusion regions probably corresponded to cell nuclei. These results were obtained with four separate cell preparations. 

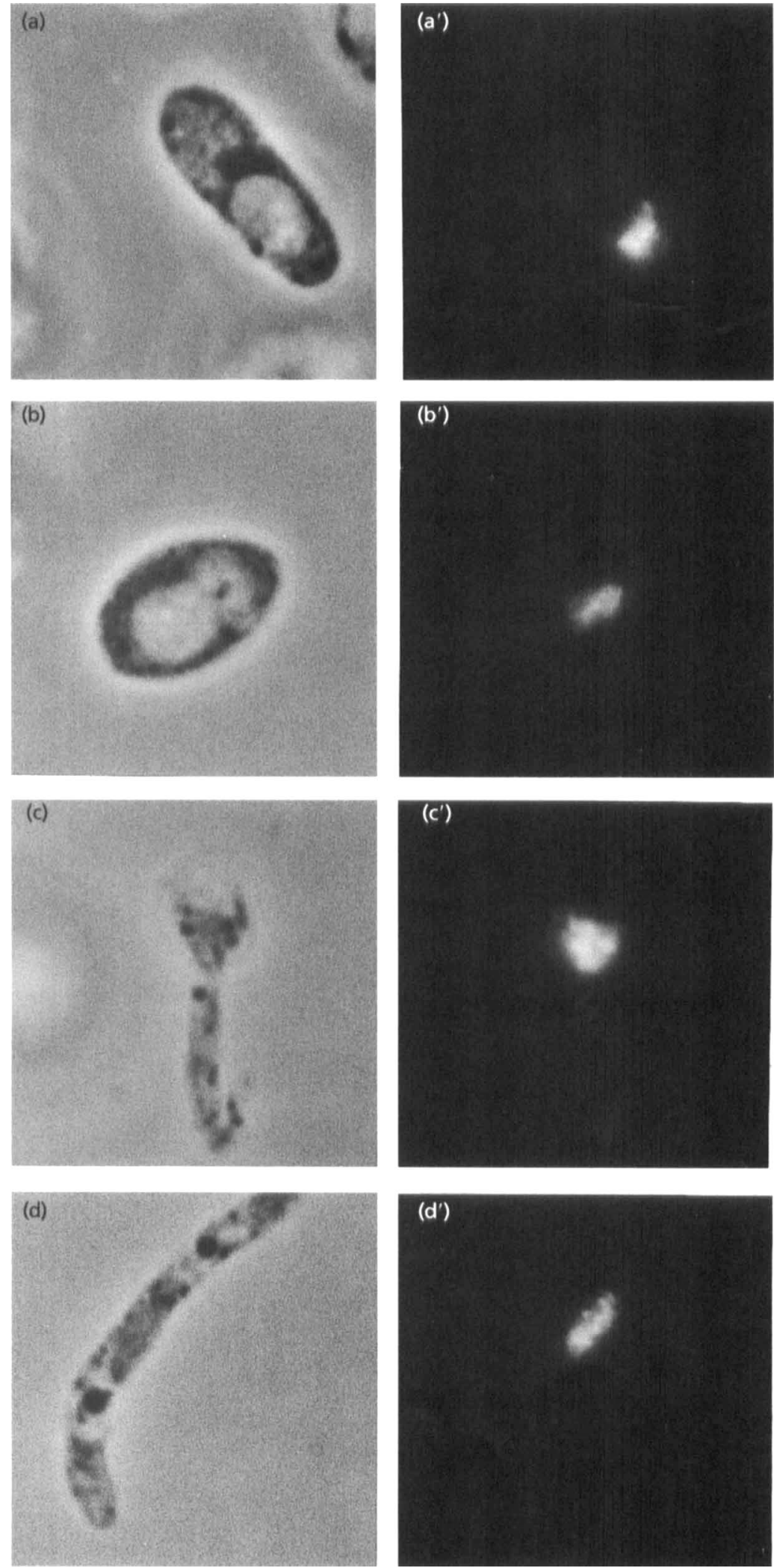

(a")
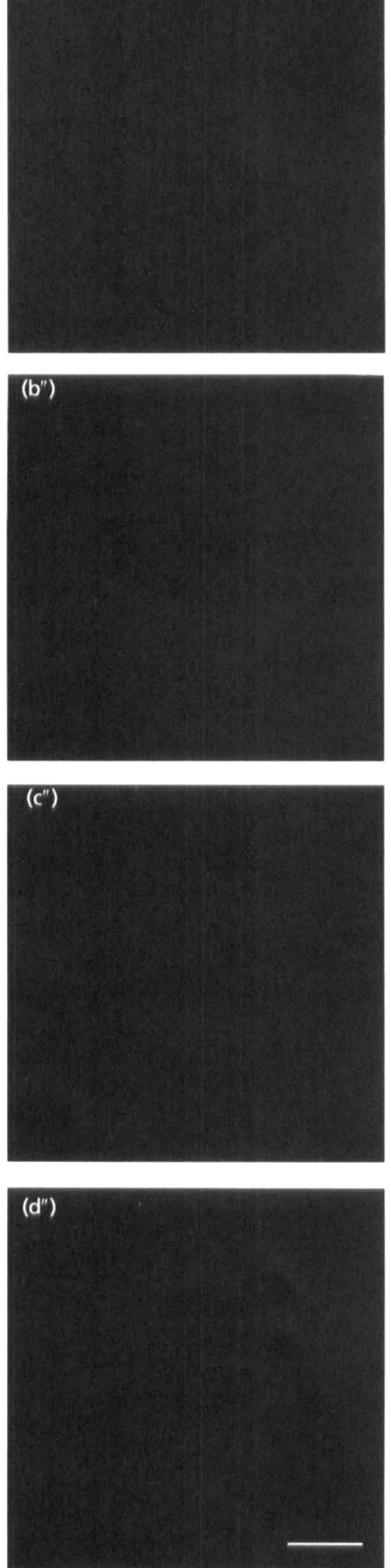

Fig. 4. Opaque phase cells and white phase hyphae do not stain with anti-rWh11 antiserum. $\left(a, a^{\prime}, a^{\prime \prime}, b, b^{\prime}, b^{\prime \prime}\right)$ Phase contrast, DAPI-stained and anti-rWh11 antiserum-stained images, respectively, of two opaque phase cells in the budding phase of growth. $\left(c, c^{\prime}, c^{\prime \prime}\right)$ Phase contrast, DAPI-stained and anti-rWh11 antiserum-stained images, respectively, of a white phase cell which has formed a hypha. (d, $\left.d^{\prime}, d^{\prime \prime}\right)$ Phase contrast, DAPI-stained and anti-rWh11 antiserum-stained images, 


\section{The anti-rWh11 antiserum stains neither opaque phase cells nor white phase budding cells which have formed hyphae}

It was previously demonstrated that neither opaque phase cells nor white phase cells forming hyphae contained signficant levels of the WH11 transcript (Srikantha \& Soll, 1993; Srikantha et al., 1995). To test whether opaque phase cells in the budding phase or white phase cells induced to form hyphae by $\mathrm{pH}$-regulated dimorphism (Buffo et al., 1984; Soll, 1986) contained the Wh11 protein, these two cell types were subjected to indirect immunofluorescent staining with anti-rWh11 antiserum and FITC-labelled goat anti-rabbit $\operatorname{IgG}$ antiserum. The same cells were also stained with DAPI to visualize nuclei. Phase contrast micrographs in Fig. $4 \mathrm{a}$ and b demonstrate the elongate shape and prominent vacuole of budding opaque cells, and DAPI-stained images of the same cells in Fig. $4 a^{\prime}$ and $b^{\prime}$ demonstrate the eccentrically located nucleus (Fig. 4a and b). Anti-rWh11 antiserum did not stain opaque phase cells (Fig. $4 a^{\prime \prime}$ and $b^{\prime \prime}$ ). This was verified by examining several stained preparations containing more than 500 opaque cells.

Hypha formation was induced by allowing white phase budding cells to enter stationary phase at $25^{\circ} \mathrm{C}$ in modified Lee's liquid medium, where they accumulate as unbudded singlets in G1 (Soll, 1986), and then diluting them into fresh medium at $37^{\circ} \mathrm{C}$, in which they synchronously form germ tubes (Buffo et al., 1984). In Fig. $4 c$, the phase contrast image is presented of a white phase budding cell which has formed a long hypha under this induction regime. DAPI staining (middle panel, Fig. $\left.4 c^{\prime}\right)$ reveals a nucleus in the original mother cell. AntirWh11 antiserum stained neither the mother cell, which contained Wh11 protein during exponential growth in the budding phase, nor the daughter hypha (Fig. 4c"). In Fig. $4 \mathrm{~d}$, a phase contrast micrograph is presented of the distal end of a hypha. DAPI staining revealed a nucleus midway along the hypha (Fig. 4d), but again anti-Wh11 antiserum did not stain the hypha (Fig. 4d"). The absence of Wh11 antigen in mother cells and hyphae was verified by examining multiple stained preparations containing more than 500 mother cells and daughter hyphae.

\section{Wh11 expression and cellular morphology in other strains of C. albicans and other species of Candida}

Using the anti-rWh11 antiserum, we tested whether the WH11 gene product is expressed in the basic o-smooth phenotype of $C$. albicans $3153 \mathrm{~A}$, two additional strains of C. albicans, CAI-4 (Fonzi \& Irwin, 1993) and an atypical strain of $C$. albicans, which biotyped as Candida dubliniensis (Sullivan et al., 1995). All strains were analysed in the budding phase and all strains expressed an antigen at $7 \mathrm{kDa}$ which stained strongly with anti-rWh11 antiserum (Fig. 5a).

We next tested whether $W H 11$ was expressed in the budding phase of other Candida species by Western blot analysis. The cell-free protein extract of budding cells of two isolates of $C$. tropicalis and one isolate each of $C$. guillermondii, $C$. lusitaniae and $C$. famata contained an antigen of approximately $7 \mathrm{kDa}$ which stained strongly with the anti-rWh11 antiserum (Fig. 5b). The cell-free protein extract of $C$. parapsilosis contained an antigen of approximately $9 \mathrm{kDa}$ which stained strongly with the anti-rWh11 antiserum (Fig. 5b). However, cell-free protein extract of $T$. glabrata (also referred to as Candida glabrata), C. kefyr and C. krusei contained no detectable cross-reacting antigen (Fig. 5c). In addition, the more distantly related species Trich. beigelii and $S$. cerevisiae, and the cellular slime mould $D$. discoideum contained no detectable cross-reacting antigen (Fig. 5c).

The expression of WH11 in WO-1 appeared to correlate with a round cell morphology, since it was expressed in the round white budding cell, but not in the elongate opaque budding cell or the elongate hypha formed by white cells (Srikantha \& Soll, 1993). We therefore assessed the expression of Wh11 in the tested $C$. albicans strains, the various Candida species and the related yeast genera in relation to their budding cell morphology. Cellular morphology was designated as either round (rnd) or elongate (elong) based upon microscopic analysis. The correlation between the presence of the Wh11 antigen and round cell morphology was suggestive, but not definitive in all cases. All C. albicans strains which showed a strongly staining Wh11 antigen in Western blots (C. albicans WO$1 \mathrm{WH}, 3153 \mathrm{~A}, \mathrm{CAI}-4$, and the atypical C. albicans strain) exhibited a round cell morphology in the budding phase of growth. The majority of other Candida species which showed a strongly staining Wh11 antigen in Western blots (C. tropicalis strains 1 and 2, C. guillermondii, $C$. lusitaniae, $C$. famata and $C$. parapsilosis) also exhibited a round cell morphology in the budding phase of growth. In the case of $C$. guillermondii, the cell population contained primarily round, but also elongate cell morphologies and, interestingly, Western blots of this species showed a slightly weaker signal (Fig. 5b). All Candida species with very low (C. shehatae) or no (C. kefyr, C. krusei) reactivity in Western blots (Fig. 5b) exhibited an elongate morphology in the budding phase of growth. C. glabrata was the only exception. It exhibited a round cell morphology in the budding phase of growth and no reactivity with anti-rWh11 antiserum (Fig. 5c). Species of the two other yeast genera analysed, Trich. beigelii and $S$. cerevisiae, did not show any reactivity with the antiserum (Fig. $5 \mathrm{c}$ ), but did show round cell morphologies. Two independent preparations of every species were stained and in every case the same staining results were obtained.

\section{DISCUSSION}

The white-phase-specific gene $W H 11$ is regulated at the level of transcription by both the white-opaque switching 

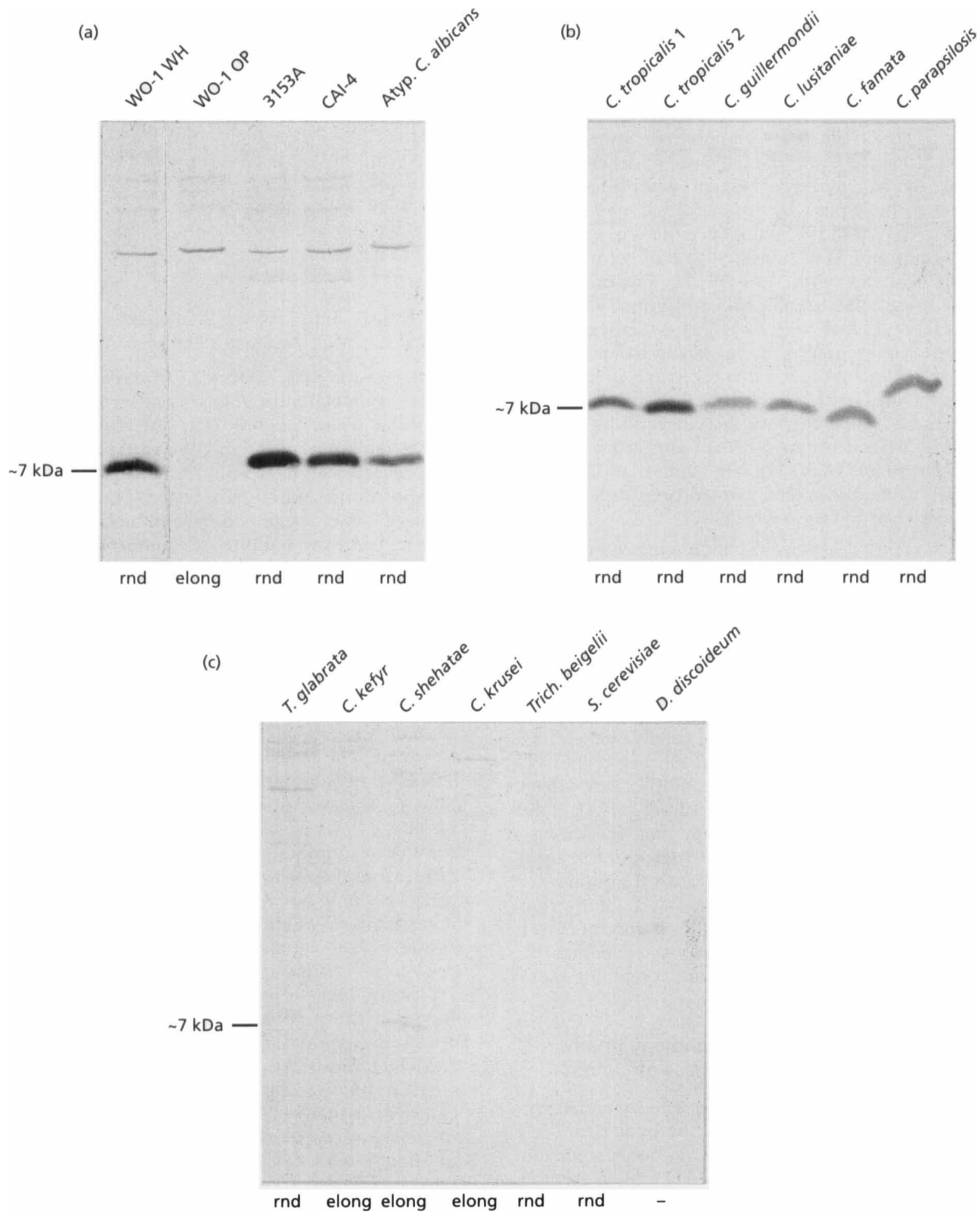

Fig. 5. Expression of Wh11 in other strains of $C$. albicans (a) and in unrelated Candida and other fungal species (b, c). The panels show Western blots of protein extracts of budding cells separated by SDS-PAGE using the anti-rWh11 antiserum. Cell morphologies were analysed microscopically and scored as either round ( $\mathrm{rnd}$ ) or elongate (elong). In the case of $D$. discoideum, a slime mould amoeba, the morphology is irrelevant $(-)$.

system and the bud-hypha transition in C. albicans WO-1 (Srikantha \& Soll, 1993). It contains an ORF encoding a putative protein of 65 amino acids with a molecular mass of approximately $7 \cdot 0 \mathrm{kDa}$. Amino acids $1-59$ of the glucose/lipid-regulated protein Glp1 of S. cerevisiae (Stone et al., 1990), which has also been identified as a heat shock 
protein referred to as Hsp12 (Praekelt \& Meacock, 1990; Varela et al., 1995), exhibits $47 \%$ homology to Wh11 (Srikantha \& Soll, 1993). Hsp12 accumulates to high levels upon heat shock, osmostress, oxidative stress and alcohol (Varela et al., 1995). Unlike Hsp12, the expression of Wh11 is regulated neither by glucose nor lipid, and does not appear to be induced by heat shock alone. Rather, expression of this gene is regulated by the two developmental programmes of $C$. albicans (switching and dimorphism), and deactivation of this gene in both programmes correlates with the formation of an elongate morphology. Recently, we demonstrated that WH11 transcription in the white phase is regulated through two transcription activation domains (Srikantha et al., 1995). A comparison of the DNA-protein complexes formed by white or opaque cell protein extracts and the individual activation domains using a gel retardation assay has revealed the existence of one or more white-phase-specific binding factors (Srikantha et al., 1995).

To begin to understand the physiological role of the WH11 gene product in both the white-opaque transition and the bud-hypha transition, we first had to map the localization of the Wh11 protein within the cell. Since the WH11 message appears to be of low abundance (Srikantha \& Soll, 1993), purifying the $W H 11$ gene product did not seem practical. We therefore generated a recombinant protein with a molecular mass similar to the native Wh11 protein, purified it to apparent homogeneity and used it to generate a polyclonal antiserum in a rabbit. The specificity of the antiserum has been verified by several criteria, including specific Western blot staining of a white-phasespecific antigen with the same molecular mass as the WH11 gene product. This antiserum was then used to immunostain white and opaque phase budding cells and white cells induced to form hyphae through the regime of pH-regulated dimorphism (Buffo et al., 1984; Soll, 1986). Anti-rWh11 antiserum stained the cytoplasm of white phase budding cells, but did not stain either the elongate opaque phase budding cell or hyphae. In white phase budding cells induced to form hyphae, the antigen was absent not only in the hypha, but also in the mother cells, which contained the antigen prior to hypha induction. This result demonstrates that the Wh11 antigen is lost sometime between entry into stationary phase and the formation of a germ tube, and suggests that it is metastable and present only during the growth of a budding cell.

The anti-rWh11 antiserum stains the cytoplasm of white phase budding cells in a punctate fashion and labelled cells viewed both by epifluorescent microscopy and confocal microscopy exhibit patterns which suggest that the antigen is either coating cytoplasmic vesicles or is distributed in the cytoplasm but excluded from vesicle interiors. Double staining of the Wh11 gene product of white budding cells with anti-rWh11 antiserum and nuclei with DAPI suggests that the Wh11 protein was excluded from the nucleus, and confocal images of anti-rWh11 antiserum-stained cells revealed an exclusion zone in each white phase cell which very likely represents the cell nucleus. The plasma membrane did not stain and there was no indication of localized staining in the cell cortex.
In addition, anti-rWh11 antiserum did not stain the cell wall. This staining pattern is similar to that of S. cerevisiae stained with antiserum against Hsp26, a small heat shock protein related to Hsp12, which has been demonstrated to be a chaperone protein (Rossi \& Lindquist, 1989).

We have explored further the suggested relationship between expression of $W H 11$ and cell shape by analysing a number of different strains of $C$. albicans and different Candida and non-Candida species for correlations between expression of the $W H 11$ gene product and budding cell morphology. We initially demonstrated that $C$. albicans $3153 \mathrm{~A}$ expressed $\mathrm{WH} 11$ in the budding but not in the hyphal growth phase (Srikantha \& Soll, 1993), as was the case for white budding cells of WO-1. However, WH11 was not deactivated in three tested variant phenotypes of the $3153 \mathrm{~A}$ switching system, even though these variant phenotypes differentially expressed the opaque-phasespecific gene OP4 (Morrow et al., 1994). Therefore, although $W H 11$ is differentially expressed in the whiteopaque transition, it is not differentially expressed in the high frequency phenotypic switching system of 3153A. However, unlike the variant opaque phenotype in the switching system of WO-1, all three 3153A switching variants grew in the budding phase with round cell morphologies, again correlating $W H 11$ expression with a round budding cell morphology. Here, we have demonstrated that three $C$. albicans strains and one atypical $C$. albicans strain express the Wh11 antigen in the budding growth phase and, in all cases, the budding cells exhibited a round cell morphology. We have also found that in addition to $C$. albicans, five additional Candida species $(C$. tropicalis, C. guillermondii, C. lusitaniae, C. famata and $C$. parapsilosis) which exhibit strong 7 or $9 \mathrm{kDa}$ bands in Western blots stained with the anti-rWh11 antiserum, also exhibit a round budding cell morphology. In contrast, three Candida species (C. kefyr, C. shehatae and C. krusez) which exhibit no stained $7 \mathrm{kDa}$ band or a very low signal, exhibit an elongate cell morphology. Species from three additional yeast genera ( $T$. glabrata, Trich. beigelii and $S$. cerevisiae) grew with a round cell morphology but exhibited no $7 \mathrm{kDa}$ signal with anti-rWh11 anti-serum. We assume that the absence of a signal in these cases is due to genetic unrelatedness. We therefore believe that the association of WH11 expression and the round cell morphology remains intact and deserves further investigation. To this end, we are in the process of generating WH11 misexpression mutants in which WH11 is under the control of an opaque promoter and is expressed in opaque cells and gene-knockout mutants which cannot express $W H 11$.

\section{ACKNOWLEDGEMENTS}

The authors are indebted to K. Jensen of the Developmental Studies Hybridoma Bank, an NIH facility centred at the University of Iowa, for help in the genesis of anti-rWh11 antiserum. This research was supported by Public Health Science grants AI23922 and DE10758 to D.R.S. K.S. was supported by the Deutsche Forschungsgemeinschaft (grant Schr-450/1-1) and S. L. was supported by Public Health Science Training grant AG00214. 


\section{REFERENCES}

Anderson, J. M. \& Soll, D. R. (1987). Unique phenotype of opaque cells in the white-opaque transition of Candida albicans. $J$ Bacteriol 169, 5579-5588.

Anderson, J., Cundiff, L., Schnars, B., Gao, M. X., Mackenzie, I. \& Soll, D. R. (1989). Hypha formation in the white-opaque transition of Candida albicans. Infect Immun 57, 458-467.

Anderson, J., Mihalik, R. \& Soll, D. R. (1990). Ultrastructure and antigenicity of the unique cell wall pimple of the Candida opaque phenotype. J Bacteriol 172, 224-235.

Bedell, G. W. \& Soll, D. R. (1979). Effects of low concentrations of zinc on the growth and dimorphism of Candida albicans: evidence for zinc-resistant and -sensitive pathways for mycelium formation. Infect Immun 26, 348-354.

Bradford, M. M. (1976). A rapid and sensitive method for the quantitation of microgram quantities of protein utilizing the principle of protein-dye binding. Anal Biocbem 72, 248-254.

Buffo, J., Herman, M. A. \& Soll, D. R. (1984). A chatacterization of pH-regulated dimorphism in Candida albicans. Mycopathologia 85, 21-30.

Fonzi, W. A. \& Irwin, M. Y. (1993). Isogenic strain construction and gene mapping in Candida albicans. Genetics 134, 717-728.

Hube, B., Monod, M., Schofield, D. A., Brown, A. J. \& Gow, N. A. (1994). Expression of seven members of the gene family encoding secretory aspartyl proteinases in Candida albicans. Mol Microbiol 14, $87-99$.

Kennedy, M. J., Rogers, A. L., Hanselmen, L. R., Soll, D. R. \& Yancey, R. J. (1988). Variation in adhesion and cell surface hydrophobicity in Candida albicans white and opaque phenotypes. Mycopatbologia 102, 149-156.

Kolotila, M. P. \& Diamond, R. D. (1990). Effects of neutrophils and in vitro oxidants on survival and phenotypic switching of Candida albicans WO-1. Infect Immun 58, 1174-1179.

Morrow, B., Srikantha, T. \& Soll, D. R. (1992). Transcription of the gene for a pepsinogen, PEP1, is regulated by white-opaque switching in Candida albicans. Mol Cell Biol 12, 2997-3005.

Morrow, B., Srikantha, T., Anderson, J. \& Soll, D. R. (1993). Coordinate regulation of two opaque-phase-specific genes during white-opaque switching in Candida albicans. Infect Immun $\mathbf{6 1}$, 1823-1828.

Morrow, B., Ramsey, H. \& Soll, D. R. (1994). Regulation of phasespecific genes in the more general switching system of Candida albicans strain 3153A. J Med Vet Mycol 32, 287-294.

Pomés, R., Gil, C. \& Nombela, C. (1985). Genetic analysis of Candida albicans morphological mutants. J Gen Microbiol 131, 2107-2113.

Praekelt, U. M. \& Meacock, P. A. (1990). HSP12, a new small heat shock gene of Saccharomyces cerevisiae: analysis of structure, regulation and function. Mol Gen Genet 223, 97-106.

Ray, T. L. \& Payne, C. D. (1990). Candida albicans acid proteinase: a role in virulence. In Candida albicans Acid Proteinase: $A$ Role in Virulence, pp. 163-178. Edited by E. M. Ayoub, G. H. Cassell, W. C. J. Branche \& T. J. Henry. Washington, DC: American Society for Microbiology.

Rossi, J. M. \& Lindquist, S. (1989). The intracellular location of yeast heat-shock protein 26 varies with metabolism. J Cell Biol 108, 425-439.

Sanger, F., Nicklen, S. \& Coulson, A. R. (1977). DNA sequencing with chain-terminating inhibitors. Proc Natl Acad Sci USA 74, 5463-5467.

Schăgger, H., Borchart, U., Machleidt, W., Link, T. A. \& Von, J. G. (1987). Isolation and amino acid sequence of the 'Rieske' iron sulfur protein of beef heart ubiquinol:cytochrome $c$ reductase. FEBS Lett 219, 161-168.

Slutsky, B., Buffo, J. \& Soll, D. R. (1985). High-frequency switching of colony morphology in Candida albicans. Science 230, 666-669.

Slutsky, B., Staebell, M., Anderson, J., Risen, L., Pfaller, M. \& Soll, D. R. (1987). 'White-opaque transition': a second high-frequency switching system in Candida albicans. J Bacteriol 169, 189-197.

Smith, D. B. \& Johnson, K. S. (1988). Single-step purification of polypeptides expressed in Escherichia coli as fusions with glutathione S-transferase. Gene 67, 31-40.

Soll, D. R. (1979). Timers in developing systems. Science 203, 841-849.

Soll, D. R. (1986). The regulation of cellular differentiation in the dimorphic yeast Candida albicans. BioEssays 5, 5-11.

Soll, D. R. (1992). High-frequency switching in Candida albicans. Clin Microbiol Rev 5, 183-203.

Srikantha, T. \& Soll, D. R. (1993). A white-specific gene in the white-opaque switching system of Candida albicans. Gene 131, 53-60.

Srikantha, T., Chandrasekhar, A. \& Soll, D. R. (1995). Functional analysis of the promoter of the phase-specific WH11 gene of Candida albicans. Mol Cell Biol 15, 1797-1805.

Stone, R. L., Matarese, V., Magee, B. B., Magee, P. T. \& Bernlohr, D. A. (1990). Cloning, sequencing and chromosomal assignment of a gene from Saccharomyces cerevisiae which is negatively regulated by glucose and positively by lipids. Gene 96, 171-176.

Sullivan, D. J., Westerneng, T. J., Haynes, K. A., Bennett, D. E. \& Coleman, D. C. (1995). Candida dubliniensis sp. nov.: phenotypic and molecular characterization of a novel species associated with oral candidosis in HIV-infected individuals. Microbiology 141, 1507-1521.

Varela, J. C., Praekelt, U. M., Meacock, P. A., Planta, R. J. \& Mager, W. H. (1995). The Saccharomyces cerevisiae HSP12 gene is activated by the high-osmolarity glycerol pathway and negatively regulated by protein kinase A. Mol Cell Biol 15, 6232-6245.

Vargas, K., Wertz, P. W., Drake, D., Morrow, B. \& Soll, D. R. (1994). Differences in adhesion of Candida albicans 3153A cells exhibiting switch phenotypes to buccal epithelium and stratum corneum. Infect Immun 62, 1328-1335.

Wessels, D., Titus, M. \& Soll, D. R. (1996). A Dictyostelium myosin I plays a crucial role in regulating the frequency of pseudopods formed on the substratum. Cell Motil Cytoskeleton 33, 64-79.

White, T. C., Miyasaki, S. H. \& Agabian, N. (1993). Three distinct secreted aspartyl proteinases in Candida albicans. J Bacteriol $\mathbf{1 7 5}$ $6126-6133$

Received 20 November 1995; revised 8 March 1996; accepted 21 March 1996. 